\title{
Fishing Community in Patron-Client Relationship and Exploitation (A Case of Small-Scale Fishing Community in Makassar)
}

\author{
Buchari Mengge \\ Doctoral Program, Departement of Sociology \\ Faculty of Social and Political Sciences \\ University of Indonesia
}

\begin{abstract}
Poverty and class exploitation are two common problems among fishing communities and an in-depth study is required to address the problems. This study aims to understand the problems and dynamics of exploitation of fishing communities in a patron-client relationship and its contribution to the subsystem production activities of the smallscale fishing communities that leads to poverty. This study reveals that class exploitation occurs in the patron-client relationship between the local investors and the fishing communities. The exploitation begins when the fishermen seek financial assistance from the local investors (collectors, punggawa, and boat owners) because of their constitutively lack of working capital. Seeking financial assistance from the local money lenders is the only solution to their problem. The relationship subsequently becomes a patron-client relationship that makes the fisherment dependent on the patrons (punggawa, collectors, and boat owners) who reap benefits from such relationship. The clients (small-scale fishermen) have to abide by a code of conduct and the patron-client relationship has restricted their production activities, which immediately leads to their worsening poverty.
\end{abstract}

Keywords: Poverty, class exploitation, patron-client relationship

\section{Introduction}

Makassar is a city at the southern tip of Sulawesi on the coast of the island facing the Makassar Strait where most of its inhabitants are fishermen who are poverty-stricken. The fishing communities in the city of Makassar are concentrated on the coastal regions, particularly the western and northern parts of the city. Some of the fishermen live in slum areas characterized by substandard housing quality. Some others even build houses along the coastal setback lines, which is considered illegal.

The poverty among the fishing communities on the coastal areas of Makassar is caused by inadequate production activities in the absence of working capital, proper gears and tools, and fishing technology. The fishermen commonly use small boats, such a non-motorized boats and boats with outboard motor (locally known as lepa-lepa andkatinting), and traditional fishing technology. The small motorboats owned and personally operated by the poor fishermen in Makassar are those boats below 5 GT. This indicates that the fishermen in Makassar have not used proper fishing technology in terms of size of boats. The size of the boats has an implication on the fishing capacity and fishing patterns. With traditional technology, the small boats have low fishing capacity and catch fish only near the shoreline. This is one of the causes of poverty among fishermen. Many researchers have found that one of the causes of poverty among fishermen is the outdated fishing technology and infrastructure (Kusnadi 2003).

It is obvious that the fishing communities in Makassar run small-scale fishing and are dominated traditional fishermen ${ }^{1}$. Why are the traditional fishermen still a marginal group? Why can't they escape their destitute condition? Many researches have the answer to these questions. Researches have found that people on the coastline live in poverty and have low socio-economic status (Kusnadi, 2003, Suyanto, 2011). The fishermen communities face intense pressure and are more fragile than any other poor groups (Suyanto, 2011). The causal analysis has inspired researchers to conduct research in poverty among fishermen and their finding is similar to that of Kusnadi (2003), Khudori (2009), Suyanto (2011), Siswanto (2008), and Retnowati (2011). They all agree that factors of poverty among fishermen are lack of skills, poor infrastructure and technology, and bad government policy.

\footnotetext{
${ }^{1}$ Kusnadi (2003) states that traditional fishing activities are characterized by: 1) rudimentary fishing technology using motorized or nonmotorized small boats with limited cruise capability, limited load capacity, limited fishing equipment; 2) limited capital; 3) small number of fishing crew consisting of only 2 to 3 people; 4) basic needs fulfillment. Law Number 7 of 2016 concerning Protection and Empowerment of Fishermen, Fishery Workers, and Salt Farmers stipulates that fishermen shall mean any individual who catches fish without fishing boat or with fishing boat below $10 \mathrm{GT}$ to fulfill their basic needs
} 
The researches also suggest that poverty is caused by exploitation of fishermen by the money lenders in a patron-client relationship. Bene (2003) has conducted some researches in Asia and Africa and he finds that poverty is the socioinstitutional mechanisms of exclusion. One of the mechanisms is class exploitation whereby persons belonging to higher class take advantage from those belonging to the lower class or whereby persons belonging to the lower class receive unfair share of profits.

This research, therefore, aims to explain and comprehensively analyze the class exploitation in a patron-client relationship among fishing communities in Makassar and its contribution to the subsystem production activities of the small-scale fishing communities that leads to poverty.

\section{Literature Review and Conceptual Framework}

The fishing community is an independent entity. It involve various relations among agents as the basic elements of a community structure. Kusnadi (2003:26) states that some agents play an important role in a fishing community. They are (1) boat and equipment owners, (2) fishing boat crew or fishing workers or locally known as nelayan buruh, and (3) informal money lenders. These agents play an important role in the life of fishing communities, especially during fishing activities. The relationship between one agent and the other, particularly between local money lenders and fishermen , has become a patron-client relationship. The money lenders who provide financial assistance, non-financial assistance, and any other social and economic insurance become the patron.

Then, why does exploitation occur? The patron-client relationship is a mutual arrangement between two parties. This is a reciprocal relationship because the patrons have social and economic superiority and other personal resources while clients benefit from their support and influence (Scott 1972, Stein 1984). This also a relationship where the clients are socially and economically far weaker than the patrons. With their superior social and economic status, the patrons wield their influence on the clients and offer protection and social and economic assistance.

Scott (1972) states that the patron-client relationship is actually a dyadic tie in which both parties expect to reap some benefits from it. The patron who has higher socio-economic status uses his own influence and resources to provide protection or benefits for a person with lower status (client) who reciprocates by offering support and assistance to the patron. At this point, the patron-client relationship is a mutual relationship because one party offers something to the other.

The inter-dependent exchange between the patron and client is the fundamental element of this type of relationship despite the fact that the inter-dependence is imbalance because the patron has more socio-economic resources to offer than does the client who is unable to repay the goods and services provided to him. When this happens, the client becomes more dependent on the patron. Imbalance is the characteristic of patron-client relationship (Scott 1972, Stein 1984) where the patron has big influence on the client, making the client more dependent on the patron. Stein (1984) suggests that the patron-client relationship is the homeostasis of injustice system. The relationship is asymmetric because the clients are inferior in terms of wealth, power, and status compared to the patrons.

This asymmetric relationship makes the clients more dependent on the patrons who will potentially exploit them. The exploitation may occur when the patrons knowing that the clients are dependent on them take more from the clients (Bene 2003). The patron will ensure that the dependence is maintained, affecting other aspects of client's life. The socio-economic protection is provided by the patron to maintain client's dependence and get benefits. The exploitation occurs because of client's heavy dependence on the patron. The patrons (money lenders and boat owners) generate more profits from the clients (fishing workers) who suffer loss because of their dependence on the patrons (Kusnadi, 2003).

In the fishing community, exploitation may results from an extremely asymmetric relation between patrons and clients (Bene 2003). The patrons, belonging to higher social class, get the benefits from the people belonging to the lower social class (clients) who work for them and who are unable to get fair share of profits. Successful patrons are those who are capable of managing and controlling the production units of the fishermen, maintaining a special relation where they use any methods, mechanism, gentle treatment, generosity, pressure, influence, intimidation, or even threat to control the fishermen (Nguinguiri 2000 in Bene 2003:964)

Having limited access to credit facilities with low interest, the fishermen get financial assistance from informal parties (local money lenders, locally referred to as dadondars) who offer credit with high interest rate that subsequently make the fishermen poorer (Islam 2013). Bene (2003) and Bene and Friend (2011) who conducted a research on the smallscale fishing business in Asia and Africa, particularly in the Mekong Valley in Asia and Volta Valley in Africa, find that the poverty among fishing communities is caused by socio-institutional menchanisms of exclusion. One of the mechanisms is class exploitation whereby persons belonging to higher class take advantage from those belonging to the lower class or whereby persons belonging to the lower class receive unfair share of profits. 
The fishing workers are vulnerable to exploitation by the local investors, especially the boat owners, who impose rules on them. The fishermen are also vulnerable to exploitation by the local money lenders who offer them credit facilities with high interest rate (Islam 2013).

Class exploitation directly leads to poverty because the investors take advantages while the fishing community suffers loss. It is the mechanism that prevents the fishing communities from enjoying their social, economic, and political rights. It is also the mechanism that prevents the fishing communities from conducting fishing activities, especially adapting to production activities. The decreasing adaptive capacity of the fishermen to various forms of pressure and structural mechanism will lead to worsening poverty. The fishermen's inability to adapt will make them uanable to cope with pressure and structural and cultural mechanism. "Fishers are not poor because they are fishers but because, like the sharecroppers, they are unable to diversify their activities' (Bene 2011;137). In this context, the adaptation strategies and poverty are inter-related and both are the case in the life of fishermen. On the one hand, poverty is the barrier that prevents the fishermen from adapting (Islam 2013). On the other hand, the fishing communities have to adapt in order that thay can cope with the pressure of poverty and class exploitation.

\section{Research Methods}

This research was conducted at the fishing communities in Makassar. It uses a qualitative method to explain and analyze the problems. It also uses various procedures and techniques of qualitative research to understand and explain the extent of exploitation faced by the fishermen and the patron-client relationship as well as its contribution to the improper production activities of the fishermen, which leads to poverty. The research begins with the selection of informants, selection of data analysis techniques and process, and data analysis. Data are collected through in-depth interviews and group discussions. The two data-collecting techniques compliment one another. The data-collecting was practically conducted from October 2015 to May 2016 although it was also conducted before and after the period, especially when completion and clarification were to be made.

\section{Result and Discussion}

\section{- Small-sclae Fishing Community in the Patron-Client Relationship and Exploitation}

The fishing community in Makassar has many members who play their respective roles as the entity of the fishing community. They can be divided into two big groups, the local investors and the fishermen. The local investors are the punggawa lelong or the fish auction owners, boat owners, and pabillolang or collectors. Punggawa lelong provide funding for the fishermen. The boat owners are the fishermen or other people owning a boat who rent their boats to the paerang or the fishing workers for operation. The collectors are the buyers of the fish the fishermen catch.

\section{Matrix of Positions and their Roles in the Small-Scale Fishing Community in Makassar}

\begin{tabular}{|c|c|c|}
\hline No & Position & Characteristics and Relation Pattern \\
\hline 1 & Punggawa lelong & $\begin{array}{l}\text { - Punggawa lelong or fish auction site owner is the buyer of the fish at the auction site (TPI) for reselling. } \\
\text { - He provides funding for the fishermen, especially the small-scale fishermen for the purchase of boat engines } \\
\text { and tools, and to cover operational costs. } \\
\text { - He controls a number of fishermen after providing them with loans. } \\
\text { - He helps sell the fish brought by the fishermen, especially those under his control, and gets } 10 \% \text { of the profit } \\
\text { earned from the sale of the fish. He will get } 5 \% \text { of the profit when he helps with the sale of the fish caught by } \\
\text { other fishermen. }\end{array}$ \\
\hline 2 & Collector/pabillolang & $\begin{array}{l}\text { - The collector is the person who buys the fish onshore of offshore. } \\
\text { The collector, locally known as pabillolang, either buy the catch by meeting the fishermen in person or } \\
\text { waiting for them at the seaport or at their house or by setting sail to meet them offshore to buy the catch. } \\
\text { The collector is one of the sources of funding for the fishermen to the procurement and repair of the boats, } \\
\text { engines, and fishing equipment. }\end{array}$ \\
\hline 3 & Boat owner & $\begin{array}{l}\text { - The boat owner is the person who owns the boat and the equipment attached to it for rent and for operation } \\
\text { by the fishermen, especially paerang. } \\
\text { - The net catch is shared equally for the owner and paerang. } \\
\text { - The cost for any damage to the boat or the fishing equipment shall be paerang's liability. }\end{array}$ \\
\hline 4 & Paerang (boat user) & $\begin{array}{l}\text { - Paerang is the user of the boat or a fisherman using other fisherman's boat because he does not own the } \\
\text { boat. } \\
\text { - The boats are those small boats below } 1 \text { to } 2 \text { GT to be operated by one person only. } \\
\text { - The net catch is shared equally for the owner and paerang. }\end{array}$ \\
\hline 5 & Fisherman & $\begin{array}{l}\text { - A fisherman is someone who owns a small boat called lepa-lepa andkatinting, or a motorized boat below } 2 \\
\text { GT. } \\
\text { - He cooperates with the pungawa lelong in the sale of the catch and financing. } \\
\text { - He cooperates with the collectors/pabillolang in the sale of the catch and financing. }\end{array}$ \\
\hline
\end{tabular}

Source: In-depth interviews and group discussion. 
Previous research has revealed that the local investors and fishermen in the fishing communities are actually involved in an exploitative relationship (Bene 2003, Thomson 2009, Nunan 2007, Kinseng 2009, Kusnadi 2003, Suyanto 2013 and Arifin 2012). The exploitation starts when the investor has control over the resources of production-something that the fishermen lack of - and, thus, force the fishermen to use them. The fishermen, having low income and limited access to low interest loans, have to turn to informal loans with higher interest. This is not only an economic exclusion process, but also an exploitation of fishermen by the local investors because they have to repay the loan and high interest. They have to work harder to repay the loan (Islam 2013).

This research confirms that the local investor-fishermen relationship is not merely a financing relationship that results from the fishermen's inability to finance themselves. It is a relationship that emerges as a result of constitutive mechanisms in fishermen's economic activities, where they are incapable in terms of working capital, mastery and ownership of fishing technology, and fishing management. The fishermen have no choice but to seek assistance from the local investors to deal with the three problems. This research finds that there are three types of patron-client relationships between the fishermen and local investors in small-scale fishing communities in Makassar City. The three types of relationships are:

First, the relationship between the fisherman and punggawa lelong. The relationship between fishermen and punggawa lelong is established in the marketing of the products. Punggawa lelong is the mediator between fishermen and buyers in the sale of catches to buyers or consumers at the Fish Auction Place (TPI). This is a mutual relationship because the fishermen need punggawa lelong in the marketing their products at TPI, while punggawa lelong need fishers so that he can retain his job at the auction site. In the process, the relationship between punggawa lelong and fisherman is no longer a mutual relationship between "sellers and retainer", as punggawa lelong perform the task beyond their capacity as a retainer, which tends to harm fishermen and benefit the retainer. This detrimental relationship occurs when the retainer begins to act as the investor by imposing a set of rules that harm the fishermen. It is important to note that one can be a punggawa lelong at the fish auction place only after he successfully make a number of fishermen regularly sell their catches through him. For him, ensuring that the fisherman sell catches through him will ensure the continuity of his position, as well as the sustainability of his profits. Punggawa lelong must offer financial assistance to the fishermen to keep them under his control and sell their catches through him.

If you want to become a boss or a punggawa lelong, you have to invest or give loans to the fishermen. This means that you must put some fishermen under your control to become a boss and sell their catches. What I mean by investing is....for example, when a fishermen plans to buy a 20-million boat, you should lend him..let's say... 5 million as an investment, depending on the amount of money the fisherman needs (Dg. Juang, results of in-depth interviews 2016)

The requirements set by punggawa lelong prior to loan disbursement are very simple and easy: the amount of the loan is flexible, no interest is charged, the amount of repayments is determined by taking into account the fishermen's ability, time and duration of repayment or installments are also flexible, and most importantly, as long as the fisherman has not repaid the debt, they must sell their catches to punggawa lelong who charges sale service fee amounting to $10 \%$ of the profit earned from the sale. The requirements may look simple and easy but the research finds that the requirements are a trap for the fishermen. The mechanism of setting requirements for loans that look simple and easy tends to harm the fishermen and benefit punggawa lelong. The $10 \%$ service charge mechanism is the thing to ponder because this is the point where punggawa lelong starts to earn profits and the fishermen begins to suffer loss. The fishermen think that $10 \%$ service charge is too much for them because their catch capacity is low and is on a day-to-day basis. Below is the illustration of the profit a punggawa lelong can earn.

Suppose that the daily income of a fisherman is $\mathrm{Rp} \mathrm{100,000} \mathrm{to} \mathrm{Rp} 200,000$ before service charge, then a punggawa lelong can earn at least Rp 10,000 to Rp 20,000 per day. In a month (with the average working days of 5 in a week), a punggawa lelong can earn $\mathrm{Rp} 200,000$ to $\mathrm{Rp} 400,000$ from a single fisherman.

It is a much bigger profit for him compared to the amount of money he spends for the loan which is below 5 million on average. If a fisherman borrows Rp 2,000,000 from him, he will earn Rp 200,000 per month only by "investing" Rp. $2,000,000$. A punggawa lelong gets bigger profit as he requires all fishermen under his control to pay a $10 \%$ service charge, regardless the amount of money he lends the fishermen. A fisherman borrowing Rp 5,000,000 has to pay the sama amount of service charge as those borrowing Rp 500,000 (Excerpt from in-depth interview 2016)

This detrimental credit arrangement that only benefits punggawa lelong is not the only problem a fisherman should deal with. There are also other requirements set by punggawa lelong, such as irregular repayment period and amount. The less money the fishermen repay for the loan and the longer the repayment period, the more profit a punggawa lelong can earn. It is a method that make him survive and a way retain this detrimental arrangement. For the fishermen, it is a disaster. When a fisherman fails to repay the loan, it is a disaster for him and a bless for punggawa lelong. Another misery that a fisherman may face is that he must sell his catches through punggawa lelong until he fully repays 
his debt. He has no other choice but to sell his catches to punggawa lelong who sets the price for his catches. A fisherman must set sails to catch fish or perform other production activities in order that he can sell his products to punggawa lelong and pay the $10 \%$ service charge.

Second, the relationship between the fisherman and collectors. This type of relationship is basically a partnership of trade between the fishermen and buyers (collectors). The fishermen sell their catches and the collectors buy them. As is the case with the relationship between the fishermen and punggawa lelong, this is not only a plain trade - the fishermen sell and the collectors buy - but a financing business that only benefits the collectors.

The relationship between the fishermen and collectors is not only a matter of buying and selling but it is also a relationship between the fishermen and investors. Oftentimes, the fishermen are the borrowers and the collectors are the money lenders (investors). When this happens, a relationship that only benefits the collectors begins. This type of relationship may be exploitative in nature because the fishermen become dependent on the collectors. Being dependent, the fishermen must sell their catches only to the collectors who authoritatively set the price. There is a tendency that the collectors selectively buy the fishermen's catches. Consequently, when the collectors only wish to buy crabs, the fishermen will catch the crabs only. This pattern of relationship obviously benefits the collectors because the fishermen must sell their catches to the collectors. With this pattern of relationship, the fishermen have no power to select who will buy their catches, to set the price for their catches, to determine what to catch, and to decide fishing patterns.

Third, the relationship between fishing workers (paerang) and boat owners. This isa mutual relationship based on a mutual agreement between the two parties. While the previous types of relationship grow from trade to financing business, this type of relationship is purely a joint operation. The boat owners rent their boat to the fishing workers. The profits are equally shared.

This type of relationship is a joint operation which is characterized by fair share of profits. However, this joint operation, in some cases, only benefits the boat owners. This happens when the boat owners also work as a punggawa lelong or a collector who offer financial assistance to the paerang. This shall mean that the relationship between them has shifted from fishing workers-boat owners relationship to investor-paerang relationship because the boat owners not only rent their boat to paerang but also provide loans to them. When this happens, the profit sharing is no longer fair as the boat owners gain more profits compared to paerang. When we refer to the analysis of Bene $(2003,2013)$, it is clear that the afore-mentioned relationship patterns are exploitative in nature. Bene (2003) refers to such relationship process and patterns as class exploitation as part of institutional mechanism for impoverishment of small-scale fishermen. The fishermen belonging to a higher social class take advantage from those belonging to the lower class or the fishermen belonging to the lower class are unable to get a fair share of the profits. Punggawa lelong and collectors or pabillolang are the group of people that take the advantage from the fishermen, especially those who are in direct contact with them.

The patron-client relationship is a common phenomenon in the fishing community and has been institutionalized and internalized. It is the safety valve (Stein, 1984) for the survival of the fishing community. The problem is that this pattern of relationship is intentionally maintained and developed by the local investors (patron: punggawa) as a system of inequality (Stein 1984) to perpetuate their interests and exploit the "culturally legitimate" fishermen (Wirutomo, 2014). When the relationship patterns become the system of inequality, the relationship itself will become exploitative where patrons (punggawa, collectors, and pabillolang) take advantage from the clients (fishermen) and take their resources away.

\section{- Correlation between Patron-Client Relationship and the Capacity of Fishermen to Adapt to Production Activities.}

Fisherman's production activities are reflected on the various adaptation strategies used by the fishing community. The small-scale fishing communities continue to diversify their capital, fishing technology, business management and marketing. (Kusnadi 2002, Thomson 2009, Islam, 2013). In the structure and culture of fishing community, capital diversification is very problematic and dilemmatic. It is very problematic because it arises from fishermen's inability to get funding from and lack of formal access to banking. Nurturing relationship with local investors (punggawa, boat owners, and collectors), however, is an adaptive action taken by the fishermen, which makes them imprisoned by the cultural forces developed by local capital owners through the mechanism of patron-client relationship. The relationship is also a dilemma for the fishermen because while it can solve their financial problem, it can lead to exploitative relationships that require them to adapt, negotiate or even resist against the exploitative relations.

The fishing community has its own adaptation strategy which is reflected in various strategic choices it uses to deal with the detrimental relationship. Even so, the choices are made by taking into account the level of patronage ties that occur between patrons and fishermen. The stronger the patronage bond, the weaker the capacity of fishermen to make adaptation choices, and the weaker the patronage bonds, the stronger the capacity of fishermen to adapt and cope with 114 
the exploitative patron-client relationships. If the patronage ties are strong and the fishing community continues to make variations in its adaptation choices, the fishermen are actually resisting the pattern of relationship, even though their resistance is secretive (disguise resistance).

Regarding the adaptation capacity, the patronage bonds in the community of small-scale fishermen can be divided into four main patterns: First, weak patronage bonds - high/multiple adaptation variations. In this pattern, the fishermen prevent themselves from engaging in production activities with the punggawa, collector or boat owner, or they terminate the ties with punggawa, collector, and boat owners. The fishing community will not do so if they are fully aware that these relationships benefit the punggawa and harm them, and at the same time they can deal with the capital problems. This way, the fishing community may perform production activities freely, especially in the diversification of capital, fishing patterns, and marketing.

Second, patronage bonds are weak variations in adaptation are low. In this pattern, the fishing community intentionally "put itself into traps" of in the patron-clients relationship and exploitation because there is a tendency that the fishermen have no adaptation choices even though their relationship with patrons (punggawa, collector, or boat owner) is not too binding, which allows them to make adaptive choices with regards to working capital, fishing patterns, variations in fishing results, and marketing patterns. This pattern still allows the fishing community to negotiate, even though the negotiations are still within the framework of patron-client relationship. They can, for example, negotiate for a longer debt repayment period, or the amount of debt repayments (installments) that fit the fisherman's financial condition. However, this shall allow for more profit for the punggawa. In this position, the fishermen has consciously or unconsciously put themselves into a trap of patron-client relationships and exploitation.



Correlation between the Patron-Client Ties and

the Capacity of Fishermen to Adapt to Production Activities

Third, patronage ties are strong - variations in adaptation are low. This pattern is actually a common pattern in patron client relationships where the fishing community is "trapped" in a patron-client relationships with punggawa. This pattern is characterized by fishermen's strong ties with the patronage, embracing the values that are difficult to dispose of in production activities. This relationship, which is bound by social and economic security created, maintained and developed by punggawa, collectors and boat owners, has been the common phenomenon for a long time,. This patronage pattern is also followed by strict supervision of the client. Because of the strong ties, the fishing community is very dependent on local investors and lacks adaptation options in production activities.

Fourth, strong patronage bonds - high/many variations in adaptation. The patron-client relationship of this pattern is actually the same as the third pattern in which patron bonds are very strong, but there is a difference in the way the problems are solved when seen from the pattern of adaptation used by the fishing community. The fishermen's resistance is sporadic, clandestine (disguise resistance), and on a daily basis (everyday resistance). 
They perform small-scale rebellious acts, such as skipping paying debt repayments or pretending that they forget to pay, turning to another punggawa without their patron knowing his action, or fleeing without repaying installments. The capacity to adapt in relation to patronage bonds has developed in fishing community. The second and third patterns are the most common patterns found in the small-scale fishing communities in Makassar. It is important to note that the patron-client relationship between fishermen and local investors is an adaptive measure taken by the fishermen to solve their working capital problems due to their destitute condition. However, this pattern is a trap-although some fishermen voluntarily put themselves into it--which limits and impedes fishermen's production activities and further perpetuates or exacerbates their poverty because local investors take more profits compared to the fishing community. At this point, class exploitation (Bene 2003), in which the investors prevent the fishing communities from gaining their rights to livelihood, takes place and leads to increasingly severe poverty. The adaptation of fishermen to overcome poverty as well as the exploitation of the local investors is actually hampered, trapped or shackled by the strong cultural values (Wirutomo 2014) in patron-client relations.

\section{Conclusion}

Poverty and class exploitation are interrelated. The patron-client relationship in the fishing community, a supposedly mutual agreement between local investors (punggawa, collector, and boat owner) and fishermen, is a case where the poverty and calss exploitation correlate to one another. The relationship is triggered by the fact that the fishing community lack resources in their production activities, especially the working capital, and they turn to local investors to seek financial assistance. This relationship has developed into a patron-client relationship where local investors use their power and influence by providing social and economic security to clients. For the fishing community, the offer serves as the safety valves that can solve any limitations and shortcomings they have in the production activities, even safety valves that can save their lives.

The relationships between local investors and fishermen are more likely to benefit local investors, which can ultimately lead to exploitation. The exploitation can be seen in the profit sharing system, sales services or profits from sales. It becomes more obvious when the fishermen are prevented from doing a number of production activities as the consequence of patron-client ties. The fishermen are trapped in the patterns of relationships and patron exploitation, where they are unable to freely carry out adaptive actions in their production activities. When this happens, exploitation through patron-client relationship will surely contribute to the diminishing adaptive capacity of fishermen, which will, in turns, perpetuate poverty among fishing communities. Poverty and class exploitation are, thus, interrelated. Exploitation and patron-client relationship occur because the poor fishermen need patrons and class exploitation will increase the severity of poverty among fishing community.

\section{References}

Arifin, Anshar (2012) Nelayan dalam Perangkap Kemiskinan, Studi Strukturasi dan Perangkap Kemiskinan pada komunitas Nelayan di Desa Tamalate, Kecamatan Galesong Utara, Kabupaten Takalar, Provinsi Sulawesi Selatan, Desertasi, Program Pascasarjana Universitas Negeri Makassar (UNM), Makassar.

Bene, Christophe and Friend, M Richard (2011), Poverty in Small-Scale Fishery: Old Issue, New Analysis, Progress in Development Studies II, 2, pp 119-144

Bene, Christhope et. al., (2009) Fish as the "Bank in the Water" Evidences from the Poor Chronic Community in Congo, Food Policy 34, pp. 108-118

Bene, Christhope (2003) When Fishery Rhymes with Poverty: A first Step Beyond the Old Paradigm on Poverty in Small-Scale Fisheries, World Development, Vol. 31 No 6. pp. 949 - 975

Garaway, Caroline (2005) Fish, Fishing, and The Rural Poor, A Case Study of the Household Importance of SmallScale fisheries in The Lao FDR, Aquatic, Resources, Culture and Development I (2), pp. 131-144

Hori, Mina et.al. (2006) Role of Small-Scale Fishing in Kampong Thom Province, Cambodia, Fisheries Science 2006: 72 , pp. 846-854

Humaedi, M. Ali (2012), Kemiskinan Komunitas Nelayan, Studi Kasus Penyebab Eksternal dan Upaya Revitalisasi Tradisi Pengentasannya di Kaliori, Rembanng, Jawa Tengah, Jurnal Sosek KP, Vol. 7 No 2 Thaun 2012

Islam, Monirul (2014) Limits and Barriers to Adaptation to Climate Variability and Change in Bangladesh Coastal Fishing Community, Marine Policy, 43 (2014) pp. 208 - 216

Jentoft, Svein, Onyango, Paul, and Islam, Mohammad Mahmudul (2010), Freedom and Poverty in the Fishery Commons, International Journal of the Commons, Vol. 4 No. 1 february 2010 pp 345 -366

and Eide, Arne, ed (2011) Poverty Mosaics, Realities and Prospects in Smal-Scale Fisheries, London and New York

Khudori (2009), Komunitas Nelayan, Kemsikinan dan Strategi Adaptasi, Koran Tempo, 12 Maret 2009 
Kinseng, Rilus A. (2011) Konflik Kelas Nelayan di Indonesia, Tinjauan Kasus Balikpapan, IPB Press, Bogor Kusnadi, (2003) Akar Kemiskinan Komunitas Nelayan, LKIS, Yokyakarta

Mills, David et.al (2011) Vulnerability in African Small-Scale Fishing Community, Journal of International Development, Vol. 23 pp.308-313 (2011)

Neiland, Arthur E, and Bene, Christhope (2004) Poverty ad Small-Scale Fishery in West Africa, Springer, London

Nunan, Fiona, (2007) Reducing Poverty Through Fisheries Co-Management: An Analysis of Design and Intention in Uganda, Journal of Development, 17, $1151-1162$

Onyango, Paul and Svein, Jentoft (2010) Assessing Poverty in Small-Scale Fisheries in Lake Victoria, Tanzania, Fish and Fisheres, 2010, 11, pp. 250-263

Pomery, Robert, Nguyen, Kim Anh Kim, and Thong, Ha Xuan (2009) Small-Scale Marine Fisheries Policy In Vietnam, Marine Policy, 33 (2009) 419 - 428

Retnowati, Endang (2011) Komunitas Nelayan Indonesia dalam Pusaran Kemiskinan Struktural (Pespektif Sosial, Ekonomi, dan Hukum), Perspektif, Vol. XVI No. 3, Hal 149-159

Scott, James C. (1990) Domination and the Arts of Resistance: Hidden Transcripts, Yale University, New Haven and London (1985) Everyday Forms of Peasant Resistance, Yale University Press, New Haven and London (1972) Patron-Client Politics and Social Change in Southeast Asia, The American Political Science Review, Vol. 66, No. 1 (Mar., 1972), pp. 91-113

Siswanto, Budi (2008) Kemiskinan dan Perlawanan Kaum Nelayan, Laksbang Mediatama, Malang (2013), Anatomi Kemiskinan dan Strategi Penangannanya, Fakta Kemiskinan Masyarakat Pesisir, Kepulauan, Perkotaan dan Danpak dari Pembangunan di Indonesia, Intrans Publishing, Malang

Stein, Howard F. (1984) A Note on Patron-Client Theory, Ethos Journal, Volume 12:1 Spring 1994, pp. 30-36

Suyanto, Bagong (2011), Mekanisme Survival, Identifikasi Kebutuhan dan Pemberdyaan Nelayan Miskin dalam Masa Kritis Akibat Kenaikan Harga BBM, Vol. 24. No. 1 Hal. 74 - 83

(2013), Anatomi Kemiskinan dan Strategi Penanganannya, Fakta Kemiskinan Masyarakat Pesisir, Kepulauan, Perkotaan dan Danpak dari Pembangunan di Indonesia, Intrans Publishing, Malang

Thomson, Keleekal (2009) Development Policies, State Interventions, and Struggles for Livelihood Rights in Coastal Communities in Kerala India, A Case Study of the Cochin Clam Fishery, Ocean and Coastal Management, 52 (2009) p. 586-592

Townsend, Peter and Gordon, David ed. (2002) World Poverty, New Policies to Defeat an Old Enemy, The Policy Press, Bristol

Venthagen, Stellan dan Johansson, Anna (2013) Everyday Resistance: Exploration of Concept and its Theories, Resistance Studies Magazine, No 1. 2013

Wirutomo, Paulus (2011) Social Development Policies on Informal Sector in Solo, International Journal of Administrative Science and Organization, Volume 18, Number 2, May 2011, pp 94-107

(2014) Sociological Reconceptualization of Social Development: With Empirical Evidence from Surakarta City, Indonesia, Asian Social Science, Vol. 10 No. 11: 2014 pp. 283-293 